УДК: $330.341 .42: 336.13$

\author{
Микола Руденко, \\ доктор економічних наук, доцент, \\ Університет банківської справи, Черкаський інститут, \\ кафедра менеджменту та IT, \\ м. Черкаси; ORCID ID 0000-0002-1966-7695 \\ e-mail: mykola_rudenko@ukr.net
}

https://doi.org/10.29038/2786-4618-2021-02-137-144

\title{
ВПЛИВ ЦИФРОВІЗАЦІЇ СІЛЬСЬКОГОСПОДАРСЬКИХ ПІДПРИЕМСТВ НА РОЗВИТОК СІЛЬСЬКИХ ТЕРИТОРІЙ
}

У статті проведено аналіз впливу цифровізації сільськогосподарських підприємств на розвиток сільських територій. Обгрунтовано трансмісійний механізм впливу цифровізації сільськогосподарських підприємств на розвиток сільських територій. Визначено можливі ефекти від цифровізації сільськогосподарських підприємств в площині економічного, соціального, організаційного та техніко-технологічного блоків. Деталізовано позитивні ефекти від цифровізації сільськогосподарських підприємств в розрізі груп основних зовнішніх сиейкхолдерів: територіальної громади, суспільства та держави. Доведено, що цифровізація сільськогосподарських підприємств сприятиме подоланню цифрового розриву між селом на міськими населеними пунктами та підвищуватиме залученість сільських територій до процесів загальної цифровізації.

Ключові слова: цифровізація, сільськогосподарські підприємства, сільські території, цифровий розрив, територіальна громада, розвиток.

Николай Руденко, доктор экономических наук, доцент, Университет банковского дела, Черкасский институт, кафедра менеджмента и ИТ, г. Черкассы

\section{ВЛИЯНИЕ ЦИФРОВИЗАЦИИ СЕЛЬСКОХОЗЯЙСТВЕННЫХ ПРЕДПРИЯТИЙ НА РАЗВИТИЕ СЕЛЬСКИХ ТЕРРИТОРИЙ}

В статье проведен анализ влияния цифровизации сельскохозяйственных предприятий на развитие сельских территорий. Обоснованно трансмиссионный механизм влияния цифровизации сельскохозяйственных предприятий на развитие сельских территорий. Определены возможные эффекты от цифровизации сельскохозяйственных предприятий в плоскости экономического, социального, организационного и техникотехнологического блоков. Детализировано положительные эффекты цифровизации сельскохозяйственных предприятий в разрезе групп основных внешних стейкхолдеров: территориальной общины, общества и государства. Доказано, что цифровизация сельскохозяйственных предприятий будет способствовать преодолению цифрового разрыва между селом на городскими населенными пунктами и повышать вовлеченность сельских территорий к процессам всеобщей цифровизации.

Ключевые слова: цифровизация, сельскохозяйственные предприятия, сельские территории, цифровой разрыв, территориальная община, развитие.

Mykola Rudenko, Doctor of Economic Sciences, Associate Professor, Banking University, Cherkasy Institute Department of Management and Information Technologies, Cherkasy

THE INFLUENCE OF DIGITALIZATION OF AGRICULTURAL ENTERPRISES ON THE DEVELOPMENT OF RURAL AREAS 
Introduction. In the fourth technological revolution, the "fuel" for the economy is digitalization, not raw materials, so at each level, there are transformational processes associated with the introduction of new digital technologies, which are designed to change the mechanisms and quality of management, improve speed and efficiency access to information and knowledge base, change the algorithms of production processes, appropriate sales channels, etc.

The purpose of the article. The purpose of the article is to analyze the transmission mechanism of the impact of digitalization of agricultural enterprises on the development of rural areas by describing the possible positive effects of digitalization in terms of the territorial community, rural population, and the state as a whole.

Results. The transmission mechanism of the influence of digitalization of agricultural enterprises on the development of rural areas is substantiated. The possible effects of the digitalization of agricultural enterprises in the plane of economic, social, organizational, and technical-technological blocks are determined. The positive effects of the digitalization of agricultural enterprises in the context of groups of major external stakeholders are detailed: the territorial community, society, and the state. It is proved that the digitalization of agricultural enterprises will help to bridge the digital divide between rural areas in urban areas and increase the involvement of rural areas in the process of general digitalization.

Conclusions. The digitalization of agricultural enterprises will have a synergistic impact on the development of rural areas. Facilitating and co-financing agricultural broadband in rural areas opens up new opportunities for its inhabitants on the road to a bright digital future and will help bridge the digital divide between cities and villages.

Keywords: digitalization, agricultural enterprises, rural areas, digital divide, territorial community, development.

Постановка проблеми та іï значення. Цифровізація є сучасним драйвером розвитку всіх без винятку секторів економіки та окремих суб'єктів господарювання. Прогрес сучасних технологій виводить сферу цифровізації на передову позицію за використанням інновацій [1]. В умовах четвертої технологічної революції «паливом» для руху економіки стає саме цифровізація, а не сировинні ресурси, тому на кожному окремому рівні відбуваються трансформаційні процеси пов'язані із впровадження нових цифрових технологій, які покликані змінити механізми та якість управлінської діяльності, покращити швидкість та оперативність доступу до інформації та бази знань, змінити алгоритми виробничих процесів, відповідні канали реалізації продукції тощо.

Багатогранність та дискусійність окремих аспектів цифровізації сільськогосподарських підприємств та їі впливу на розвиток сільських територій зумовлюють необхідність у поглибленні досліджень в окресленому напрямку. Особливо за умов реалізації сучасної концепції ведення «розумного» аграрного виробництва та його впливу на розвиток територіальної громади, сільського населення та держави вцілому.

Аналіз останніх досліджень і публікацій. Проблематика дослідження впливу сучасних технологій на інноваційний розвиток сільських територій не є нової для аграрної економічної науки, серед усієї сукупності робіт виділимо праці М. Лобаса, В. Россохи [2], Ю. Лупенка, М. Маліка [3] та Н. Сіренко [4]. Процеси впливу саме цифровізації на розвиток аграрних суб'єктів господарювання знайшли відображення в працях Ю. Волощук [5], О. Гудзь [6], Т. Конєвої [7], М. Кропивка [8] та інших. Віддаючи належне зазначеним науковцям підкреслимо, що динамізм процесів діджиталізації сільськогосподарських підприємств та їх постійний вплив на розвиток сільських територій зумовлюють необхідність у поглибленні досліджень в окресленому напрямі.

Мета і завдання дослідження. Мета статті - провести аналіз трансмісійного механізму впливу цифровізації сільськогосподарських підприємств на розвиток сільських територій шляхом опису можливих позитивних ефектів від діджиталізації в розрізі територіальної громади, сільського населення та держави вцілому.

Виклад основного матеріалу та обгрунтування отриманих результатів дослідження. Застосована в статті методологія передбачає обгрунтування трансмісійного механізму впливу цифровізації сільськогосподарських підприємств на розвиток сільських територій, тому деталізуємо алгоритм проведення дослідження: 1) опишемо конкретні завдання, котрі можливо вирішити за рахунок цифровізації сільськогосподарських підприємств в межах окремих блоків; 2) деталізуємо інструменти використання яких сприятиме розв'язанню описаних проблем; 3) запропонуємо конкретні рішення та охарактеризуємо можливі результати (ефекти) використання інструментів сформованих за рахунок цифровізації діяльності сільськогосподарських підприємств.

Цифровізація будь-якої діяльності неможлива без доступності технологій та наявності засобів комунікації, деталізовано окреслені аспекти описано в авторській монографії [9], проте в сільській місцевості, а особливо у віддалених територіальних громадах, існують значні проблеми із доступністю технологій, на сам перед Інтернет зв'язку. За даними Інтернет асоціації України [10] протягом всіх років дослідження прослідковується стала тенденція до суттєвого відставання по кількості користувачів Інтернет зв'язком між містами та селами. Наприклад відставання у 2019 році між містами з населенням більше 100 тис. жителів та селами складало $16 \%$, хоча треба зауважити, що останніми роками зазначене відставання дещо скорочується за рахунок реалізації програм встановлення мобільними операторами сучасних базових станцій стільникового зв'язку і відповідно 
користування мобільним Інтернетом, хоча комплексно зазначені дії проблему не вирішують. Тому вищесказане формує значну цифрову нерівність між містами та сільськими населеними пунктами.

Вважаємо, що основними інструментами подолання даної нерівності $є$ проведення широкосмугового Інтернету в села (через прокладання оптично-волоконного кабелю), проте проблема криється у фінансуванні зазначених заходів. Існує кілька варіантів фінансування цифровізації в сільській місцевості: власним коштом громадян; за допомогою залучення інвестицій провайдера (підприємства надавача послуг доступу до мережі Інтернет); залучення грантів та коштів фонду регіонального розвитку; субвенції держави на розвиток інфраструктури об'єднаних територіальних громад; інвестиції окремих фізичних та юридичних осіб (меценатів).

Зростання проникнення Інтернету в села останніми роками здебільшого відбулося за рахунок смартфонізації сільських територій і доступу до Інтернету саме через цей канал зв’язку. Оператори ринку фіксованого доступу до Інтернету, на основі власних розрахунків, доводять, що сьогодні 60-70 \% вітчизняних сіл є просто нерентабельними для їх бізнесу з точки зору вартості інвестування фінансових ресурсів у прокладання дротового Інтернету і окупності вкладених фінансових ресурсів. Іншим важливим аспектом проблеми є відносно висока вартість користування послугами доступу до мережі Інтернет в сільській місцевості, оскільки кількість користувачів в селі значно менше ніж в містах і відповідно вартість зростає пропорційно кількості підключених, якщо в містах середня місячна вартість користування мережею коливається в межах 100 150 грн, то в селі середня вартість складає від 200 до 300 грн місяць і суттєво залежить від віддаленості населеного пункту.

На нашу думку, цифровізація сільськогосподарських підприємств частково сприятиме вирішенню окреслених вище проблем, оскільки самі підприємства потребують доступу до мережі, що спонукає останніх шукати шляхи та реалізовувати заходи проведення Інтернету на підприємство і, як наслідок, заводити його в населений пункт свого розташування. Нами пропонується часткове співфінансування проведення Інтернету у територіальну громаду за рахунок підприємств і самої громади в розмірі 30\% видатків - підприємство, решта громада. Проведені дослідження показують, що в окремих випадках можливо здійснювати оплату послуг із проведення Інтернету в розмірі 50\% на 50\%. Особливо цінним може бути використання сільськогосподарської техніки при укладанні кабелю швидкісного Інтернету, що значно пришвидшить процес доступу до базових умов цифровізації і здешевить процес його реалізації.

Розширення можливостей доступу до мережі Інтернет у сільській місцевості здійснить інтегральний вплив на розвиток територіальної громади, суспільства та держави в цілому. На нашу думку, можливі позитивні наслідки необхідно розглядати в площині економічного, соціального, організаційного та техніко-технологічного ефектів (рис. 1).

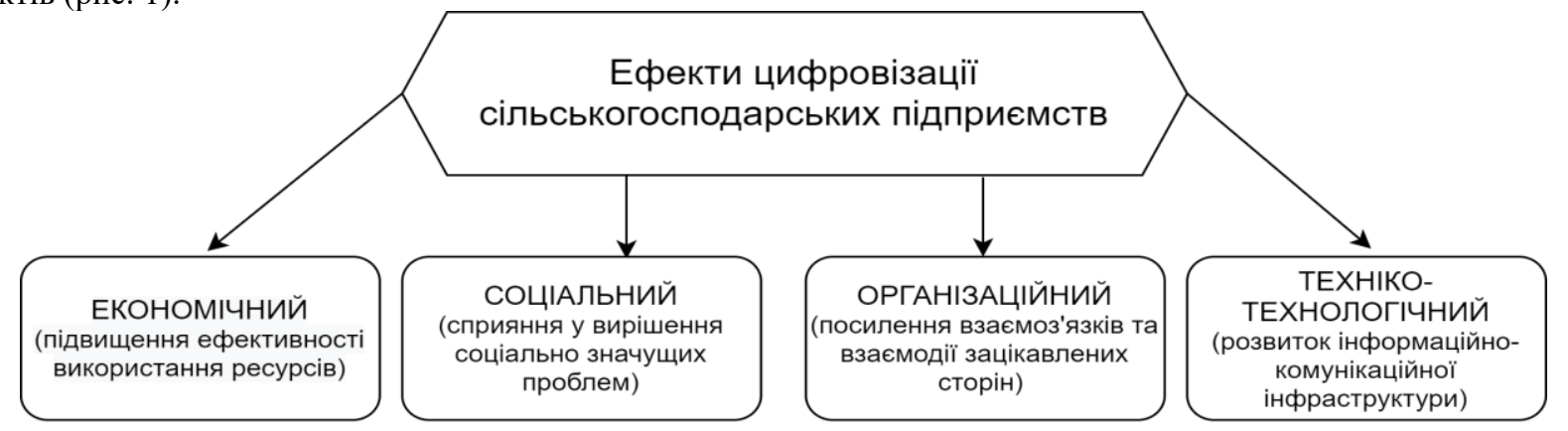

Рис. 1. Ефекти ичифровізації сільськогосподарських підприємств

Джерело: складено автором

Одним 3 найважливіших блоків є економічний, оскільки серед сільського населення (12,76 млн. або 30,4 \% від усього наявного населення, станом на 2020 рік [11]) близько 3,25 млн. осіб - це працюючі, причому 56,3 \% із числа зайнятих працювали за межами свого населеного пункту, переважно в містах на селищах міського типу, а також з кожним роком збільшується чисельність працюючих за кордоном. Тому проблема працевлаштування та ділової активності в сільських територіях стоїть надзвичайно гостро.

На зайнятість сільського населення значним чином впливає наявність місць роботи (підприємств) та доступність технологій, у понад 35 \% сіл взагалі відсутні будь-які господарюючі суб'єкти (окрім магазинів та сфери послуг), що фактично унеможливлює зайнятість населення в межах свого місця проживання. Саме тому чи не єдиним механізмом забезпечення часткової зайнятості залишається доступність технологій (Інтернет з'єднання). Економічним ефектом для сільських територій від цифровізації сільськогосподарських підприємств можна вважати додаткову зайнятість через можливості доступу до технологій та дистанційної роботи. Доступність технологій значним чином підвищують інвестиційну привабливість громади за рахунок можливостей розвитку еко-туризму, що дозволить територіальній громаді презентувати свої туристичні 
можливості та інвестиційні об’єкти, а також працювати над брендом території. Це скоротить шлях до інвестора i зробить територіальну громаду впізнаваною в інформаційному просторі.

Іншим важливим економічним аспектом для громади сільських територій є мінімізація паперової роботи через механізми автоматичного формування звітності різних рівнів, автоматизації роботи 3 документами (перехід до електронної взаємодії із державними установами різних рівнів), приєднання до систем електронної взаємодії органів виконавчої влади (СЕВ ОВВ) та система взаємозв’язку реєстрів «Трембіта».

За рахунок доступності технологій суспільство, в особі жителів громади, та інших зацікавлених сторін отримують доступ до всіх он-лайн державних послуг не виходячи з дому, що значним чином скоротить витрати фінансових ресурсів на поїздки у місто та зекономить час на отримання необхідних документів та довідок. У моделі сервісно-орієнтованої держави, до якої переходить Україна, надання державою послуг є найважливішою функцією державних структур. Однією з головних цілей Міністерства цифрової трансформації до 2024 року $є$ оцифрування 100 \% послуг, які надає держава. Для цього створений портал «Дія» (https://diia.gov.ua/). На порталі можна отримати он-лайн більше 50 державних послуг, наголошує міністр цифрової трансформації Михайло Федоров [12], серед яких:

-є Малятко;

- реєстрація місця проживання дитини;

- будівельні послуги;

- оформлення допомоги по безробіттю;

- запис до листа очікування вакцинації від COVID-19.

За словами міністра [12], станом на березень 2021 року портал «Дія» має більше 3,6 мільйонів відвідувань та більше 275 тисяч українців успішно скористалися послугами. Також громадяни отримають можливість перевірити наявну інформацію про себе із п'яти державних реєстрів і все це можна зробити не виходячи 3 власного подвір'я, тому доступність технологій в сільській місцевості не просто необхідність, а вимога часу. Вважаємо, що доступність технологій у сільській місцевості, значним чином збільшить кількість користувачів послуг, на нашу думку, збільшення можливе в межах 15-20\%, оскільки третина населення країни - це жителі сільських територій. Наявність технологій також відкриває суттєві можливості доступу до інформації та бази знань, що в наш час $є$ відправною точкою появи нових бізнес ідей і майбутніх здобутків.

Економічний розвиток сільських територій, а особливо віддалених територіальних громад, сприятиме загальному економічному розвитку держави через залученість все більшої кількості населення у цифровий простір. Як наслідок очікується збільшення (хоча і не суттєве) податкових надходжень та поліпшення структури зайнятості, що позитивно вплине на формування валового внутрішнього продукту. Покращення Інтернет-мережі на сільських територіях дозволить більшій кількості населення використовувати електронні можливості, що збільшить попит та конкуренцію в цифровій економіці.

Соціальний ефект від цифровізації сільськогосподарських підприємств спрямований на розвиток вітчизняної моделі соціально-орієнтованої ринкової економіки. Соціальний ефект проявляється у появі нових цифрових можливостей для територіальних громад, суспільства та держави. Соціальна складова цифровізації територіальних громад передбачає можливості залучення людей з особливими потребами до суспільного життя та доступ до інклюзивної освіти. Інклюзивна освіта - достатньо нове поняття для України, де загальний показник інклюзії в межах 10 \% (станом на кінець 2020 року). Однак, попри радянську спадщину сегрегації та нехтування людьми з інвалідністю, країна зробила величезні кроки на шляху до інклюзивного суспільства. Серед 700 тис. дітей з інвалідністю в Україні понад 168 тис. мають особливі освітні потреби, третина 3 яких проживає у сільській місцевості. У 2017 році вперше у вітчизняній історії до Закону України «Про освіту» внесли положення про захист дітей з особливими освітніми потребами, а вже у 2018 році з державного бюджету України виділено значне фінансування на створення рівних умов для дітей з особливими освітніми потребами 509 млн. грн. Доступність інклюзивної освіти у кожному місті та селі, по всій Україні, потребує перш за все доступності технологій отримання освіти, а саме доступу до швидкісного Інтернету, як базової умови долучення до інклюзивних освітніх процесів.

Важливим соціальним ефектом для територіальної громади є відкриття можливостей дистанційної роботи та навчання. Карантинні заходи пов'язані із розповсюдженням вірусу COVID-19, довели необхідність розвитку інформаційно-комунікаційних технологій у сільській місцевості, на нашу думку, синергетична взаємодія сільськогосподарських підприємств 3 територіальною громадою здатна покращити можливості доступу до технологій, в тому числі за рахунок організації на базі підприємства або будинку культури села (як для дітей співробітників, так і для всіх охочих) класів доступу до Інтернету, що на практиці дозволить реалізовувати концепцію дистанційного навчання на селі не на папері, а в реальності.

Суспільство акумулюватиме соціальний ефект від цифровізації сільськогосподарських підприємств за рахунок:

- по-перше, підвищення цифрової грамотності населення, долученість до урядового он-лайн-проекту «Дія. Цифрова освіта» - програму з підвищення цифрової грамотності українців, яка розпочала свою роботу $з$ січня 
2020 року. За даними Міністерства цифрової трансформації 37,9 \% українців у віці 18-70 років володіють цифровими навичками нижче середнього рівня, а 15,1 \% населення взагалі не мають цифрових навичок;

- по-друге, соціальний ефект цифровізації для суспільства проявляється у можливостях значного полегшення комунікації між людьми не лише в межах країни, але і за кордоном;

- по третє, розширення цифрових навичок є ключовою умовою для розвитку цифрового ринку країни, оскільки останній прямо або опосередковано пов'язаний з усіма сферами функціонування суспільства та економіки;

- по-четверте, ефектом для суспільства є покращення соціального захисту через механізми дистанційного доступу до різних державних послуг, в тому числі отримання необхідних довідок, запису до фахових медпрацівників, реєстрації документів тощо.

Соціальним ефектом на рівні держави є зменшення відтоку молоді з сільських територій та збільшення иіi зайнятості, що тісно корелює із завданнями, які ставив перед собою уряд в межах плану заходів 3 реалізації Концепції розвитку сільських територій (№ 489-р від 19.07.2017 року) [13]. Також соціальним ефектом вважатиметься загальне покращення якості життя мешканців сільських територій та інклюзивний розвиток регіонів, який має низьку динаміку позитивних зрушень та наявність значної міжрегіональної асиметрії.

Організаційним ефектом цифровізації, в межах територіальної громади, є оптимізація адміністративноуправлінських видатків громади за рахунок скорочення витрат на різні форми зв'язку та окремі види послуг (банківських, інформаційно-консультативних), які можливо отримати он-лайн, а також оптимізація організаційної структури виконавчих органів місцевого самоврядування. Мешканцям сільських територій відкриваються можливі доступу до електронного урядування та електронної демократії, в межах урядових програм «Про схвалення Концепції розвитку електронного урядування в Україні» [14] та «Про схвалення Концепції розвитку електронної демократії в Україні та плану заходів щодо ії реалізації» [15], що дозволить долучитися до контролю за результативністю та ефективністю діяльності органів державної влади та органів місцевого самоврядування, а також надання можливості безпосередньої участі людини в процесах підготовки та експертизи проектів адміністративних рішень. Для держави, організаційний ефект проявляється у площині можливостей просування адміністративної реформи вглиб сільських територій, що сприятиме швидкій комунікації та взаємодії між центром та територіальними громадами.

Технологічним ефектом для територіальної громади $є$ можливість запровадження та підтримки власного сайту в мережі Інтернет. Згідно чинного законодавства в об'єднаній територіальній громаді має бути свій сайт. Загальний перелік вимог до порталу закріплений у постанові Кабінету міністрів України від 12.06.2019 р. № 493 «Про внесення змін до деяких постанов Кабінету Міністрів України щодо функціонування 20 офіційних вебсайтів органів виконавчої влади» [16] та наведених на веб-порталі «Дизайн система державних сайтів України» (design.gov.ua). Доступність цифрових технологій навіть у віддалених громадах є безперечною перевагою для мешканців сільських територій, оскільки розширюються можливості залишатися «он-лайн» на більшій територій, що робить дистанційну роботу та освіту більш доступною в незалежності від географічного розташування.

Держава, в особі органів виконавчої влади, отримає технологічний ефект від цифровізації сільськогосподарських підприємств за рахунок розширення можливостей інформаційно-комунікаційного розвитку сільських територій в межах урядової концепції № 489-р від 19.07.2017 року [13], а саме в блоці освіти та інформаційно-консультаційного забезпечення, в якому планувалося проведення інформаційнороз'яснювальної і консультаційної роботи в аспекті навчання для сільських громад 3 метою їх участі в розробленні проектів залучення міжнародної технічної допомоги для формування локальних проектів розвитку сільських територій.

На основі проведеного дослідження сформовано підсумкову таблицю впливу кожного окремого блоку ефектів на розвиток сільських територій (табл. 1).

Позитивні ефекти від цифровізації сільськогосподарських підприсмств

Таблиия 1

\begin{tabular}{|c|l|l|l|}
\hline Ефект & \multicolumn{1}{|c|}{ Територіальна громада } & \multicolumn{1}{|c|}{ Суспільство } & \multicolumn{1}{|c|}{ Дерава } \\
\hline Економічний & - додаткова зайнятість & - доступ до всіх он-лайн & - збільшення податкових \\
& жителів громади & послуг не виходячи 3 & надходжень; \\
& (зменшення безробіття); & дому; & - зростання валового \\
& - скорочення паперової & - скорочення витрат & внутрішнього продукту; \\
& роботи; & фінансових ресурсів і & - економічний розвиток \\
& - покращення іміджу та & часу на отримання & сільських територій; \\
& підвищення ділової & послуг; & - підвищення рейтингових \\
& активності; & - швидкий доступ до & індексів цифровізації (IDI, \\
& - інвестиційна & інформації та бази знань; & DESI, DAI). \\
& привабливість громади; & - підзвітність і контроль & \\
\hline
\end{tabular}




\begin{tabular}{|c|c|c|c|}
\hline & $\begin{array}{l}\text { - зростання податкових } \\
\text { надходжень. }\end{array}$ & органів влади. & \\
\hline Соціальний & $\begin{array}{l}\text { - доступність інклюзивної } \\
\text { освіти; } \\
\text { - залученість людей з } \\
\text { особливими потребами до } \\
\text { суспільного життя; } \\
\text { - можливості дистанційної } \\
\text { роботи та навчання; } \\
\text { - долученість до зовнішньої } \\
\text { комунікації; } \\
\text { - подолання цифрової } \\
\text { нерівності. }\end{array}$ & $\begin{array}{l}\text { - покращення } \\
\text { соціального захисту; } \\
\text { - підвищення цифрової } \\
\text { грамотності населення (в } \\
\text { межах 2-3\%); } \\
\text { - зростання освіченості } \\
\text { громадян; } \\
\text { - зниження корупційних } \\
\text { ризиків; } \\
\text { - полегшення } \\
\text { комунікації. }\end{array}$ & $\begin{array}{l}\text { - зменшення відтоку } \\
\text { молоді з сільських } \\
\text { територій; } \\
\text { - збільшення зайнятості } \\
\text { населення; } \\
\text { - покращення якості життя } \\
\text { громадян; } \\
\text { - інклюзивний розвиток } \\
\text { регіонів; } \\
\text { - можлива трудова } \\
\text { міграція з міста в село. }\end{array}$ \\
\hline $\begin{array}{c}\text { Організацій- } \\
\text { ний }\end{array}$ & $\begin{array}{l}\text { - оптимізація } \\
\text { адміністративно- } \\
\text { управлінських витрат; } \\
\text { - прискорення бізнес- } \\
\text { процесів; } \\
\text { - доручення до розвитку } \\
\text { зовнішніх партнерів. }\end{array}$ & $\begin{array}{l}\text { - доступність } \\
\text { електронного } \\
\text { урядування; } \\
\text { - участь громадян у } \\
\text { формуванні і прийнятті } \\
\text { рішень громади. }\end{array}$ & $\begin{array}{l}\text { - просування } \\
\text { адміністративної реформи; } \\
\text { - швидка комунікація між } \\
\text { центром та } \\
\text { територіальними } \\
\text { громадами. }\end{array}$ \\
\hline $\begin{array}{c}\text { Технологіч- } \\
\text { ний }\end{array}$ & $\begin{array}{l}\text { - технічна можливість } \\
\text { функціонування сайту } \\
\text { громади; } \\
\text { - покращення } \\
\text { комунікаційної } \\
\text { інфраструктури та } \\
\text { оновлення технологічної } \\
\text { бази громади. }\end{array}$ & $\begin{array}{l}\text { - доступність цифрових } \\
\text { технологій на віддалених } \\
\text { територіях. }\end{array}$ & $\begin{array}{l}\text { - технологічний розвиток } \\
\text { сільських територій (в } \\
\text { межах урядової концепції } \\
\text { № 489-р від 19.07.2017 р.). }\end{array}$ \\
\hline
\end{tabular}

Джерело: складено автором

Висновки i перспективи подальших досліджень. Таким чином, цифровізація діяльності сільськогосподарських підприємств матиме синергетичний вплив на розвиток сільських територій. Сприяння та співфінансування сільськогосподарськими підприємствами проведення широкосмугового Інтернету в сільські території відкривають нові можливості для його мешканців на шляху до світлого цифрового майбутнього та сприятиме подоланню цифрового розриву між містами та селами.

Розуміючи складну ситуацію з інфраструктурою села та нестачею коштів у місцевої та центральної влади на реалізацію великих інфраструктурних проектів, доступ до Інтернету залишається чи не єдиним інструментом включення сільських територій до сучасних процесів цифровізації та глобалізації. Переконані, що на державному рівні необхідно затвердити та реалізовувати на практиці Національний план розвитку широкосмугового Інтернету, як елементу стратегії цифровізації, із відповідним залученням всіх зацікавлених сторін, як базового елементу стратегії соціально-економічного розвитку сільських територій.

У подальших дослідженнях зазначені висновки можуть бути використані при формуванні науковопрактичних пропозицій щодо розробки дієвих механізмів реалізації програми подолання цифрового розриву та залученості сільських територій до процесів цифровізації в межах плану роботи Міністерства цифрової трансформації України.

\section{Джерела та література}

1. Пантєлєєва Н. М., Колодій С. Ю., Ребрик М. А. Цифрова економіка як ключовий тренд розвитку постіндустріального суспільства: монографія. К.: ДВНЗ «Університет банківської справи», 2019. 299 с.

2. Лобас М. Г., Россоха В. В., Соколов Д. О. Управління інноваційно-технологічним розвитком агросфери: монографія. К.: ННЦ IAЕ, 2016. 416 с.

3. Лупенко Ю. О., Малік М. Й., Шпикуляк О. Г. Інноваційне забезпечення розвитку сільського господарства України: проблеми та перспективи: монографія. К.: ННЦ IАЕ, 2014. 514 с.

4. Сіренко Н. М., Мельник О. І. Інноваційне підприємництво як складова стратегії розвитку аграрного сектора економіки. Миколаївський національний аграрний університет. $2013 . \quad$ URL: https://www.sworld.com.ua/simpoz2/105.pdf 
5. Волощук Ю. О. Напрями цифровізації аграрних підприємств. Ефективна економіка. 2019. №2. URL: http://www.economy.nayka.com.ua/pdf/2_2019/68.pdf (дата звернення 20.04.2021).

6. Гудзь О. С., Федюнін С. А., Щербина В. В. Диджиталізація, як конкурентна перевага підприємств. Економіка. Менеджмент. Бізнес. 2019. №3(29). С. 12-19.

7. Конєва Т. А. Особливості впровадження інновацій сільськогосподарськими підприємствами України. Наукові праці Чорноморського державного університету імені Петра Могили. Серія «Економіка». 2016. Т. 285, Вип. 273. С. 101-106.

8. Kropyvko M. Estimation of digitalization investment projects in agricultural enterprises. Financial and credit activity: problems of theory and practice. 2020. Vol. 4 (35), P. 212-219.

9. Руденко М. В. Цифровізація сільськогосподарських підприємств та іiі економічна ефективність: монографія. Черкаси: видавець Чабаненко Ю. А., 2020. 342 с.

$\begin{array}{ccccc}10 . & \text { Проникнення } & \text { внтернету } & \text { Україні. URL: }\end{array}$ https://inau.ua/sites/default/files/file/1910/dani_ustanovchyh_doslidzhen_2019 roku.pdf (дата звернення 20.04.2021).

11. Офіційний сайт Державної служби статистики України. Населення України. URL: http://www.ukrstat.gov.ua (дата звернення 20.04.2021).

12. У «Дії» можна отримати понад 50 послуг. URL: https://www.pravda.com.ua/news/2021/03/30/7288317 (дата звернення 20.04.2021).

13. Про затвердження плану заходів з реалізації Концепції розвитку сільських територій: Закон України від 19.07.2017 p. № 489-p. URL:https://zakon.rada.gov.ua/laws/show/489-2017-\%D1\%80 (дата звернення 20.04.2021).

14. Про схвалення Концепції розвитку електронного урядування в Україні: Розпорядження Кабінету Міністрів України від 20.09.2017 р. № 649-p URL: https://www.kmu.gov.ua/npas/250287124 (дата звернення 20.04.2021).

15. Про схвалення Концепції розвитку електронної демократії в Україні та плану заходів щодо їі реалізації: Розпорядження Кабінету Міністрів України від $08.11 .2017 \quad$ p. № $797-p$ URL:https://zakon.rada.gov.ua/laws/show/797-2017-\%D1\%80 (дата звернення 20.04.2021).

16. Про внесення змін до деяких постанов Кабінету Міністрів України щодо функціонування офіційних веб-сайтів органів виконавчої влади. Постанова Кабінету Міністрів України від 19.06.2019 p. № 493 URL: https://zakon.rada.gov.ua/laws/show/493-2019-\%D0\%BF (дата звернення 20.04.2021).

\section{References}

1. Panteleeva, N. M. Kolodii, S. Yu. \& Rebryk, M. A. (2019). Tsyfrova ekonomika yak klyuchova tendentsiya rozvytku postindustrial'noho suspil'stva [Digital economy as a key trend in the development of post-industrial society], Kyiv: DVNZ «Universytet bankivs'koyi spravy» [In Ukrainian].

2. Lobas, M. G., Rossokha, V. V. \& Sokolov, D. O. (2016). Upravlinnya innovatsiyno-tekhnolohichnym rozvytkom ahrosfery [Management of innovation and technological development of the agrosphere]. Kyiv: NNTS IAE [In Ukrainian].

3. Lupenko, Yu. O., Malik, M. Y. \& Shpykulyak, O. G. (2014). Innovatsiyne zabezpechennya rozvytku sil's'koho hospodarstva Ukrayiny: problemy ta perspektyvy [Innovative support of agricultural development of Ukraine: problems and prospects]. Kyiv: NNTS IAE [In Ukrainian].

4. Sirenko, N. M. \& Mel'nyk, O. I. (2013). Innovatsiyne pidpryyemnytstvo yak skladova stratehiyi rozvytku ahrarnoho sektora ekonomiky [Innovative entrepreneurship as a component of the strategy of development of the agricultural sector of the economy]. Mykolayivs'kyy natsional'nyy ahrarnyy universytet - Mykolayiv National Agrarian University. Retrieved from: https://www.sworld.com.ua/simpoz2/105.pdf [In Ukrainian].

5. Voloshchuk, Yu. O. (2018). Napryamy tsyfrovizatsiyi ahrarnykh pidpryyemstv [Areas of Digitization of Agrarian Enterprises]. Efektyvna ekonomika - Efficient economy, 2. Retrieved from: http://www.economy.nayka.com.ua/pdf/2_2019/68.pdf [In Ukrainian].

6. Hudz, O. Ye., Fedyunin, S. A. \& Shcherbina, V. V. (2019). Dydzhytalizatsiya, yak konkurentna perevaha pidpryyemstv [Digitalization as a competitive advantage of enterprises]. Ekonomika. Menedzhment. Biznes - Economy. Management. Business, 3(29), pp. 12-19 [In Ukrainian].

7. Konyeva, T. A. (2016). Osoblyvosti vprovadzhennya innovatsiy sil's'kohospodars'kymy pidpryyemstvamy Ukrayiny [Features of the introduction of innovations by agricultural enterprises of Ukraine]. Naukovi pratsi Chornomors 'koho derzhavnoho universytetu imeni Petra Mohyly. Seriya «Ekonomika» - Scientific works of the Black Sea State University named after Petro Mohyla. Economics series, Vol. 273, pp. 101-106 [In Ukrainian].

8. Kropyvko, M. (2020) Estimation of digitalization investment projects in agricultural enterprises. Financial and credit activity: problems of theory and practice, Vol. 4 (35), pp. 212-219 [In English].

9. Rudenko, M. V. (2020). Tsyfrovizatsiya sil's'kohospodars'kykh pidpryyemstv ta yiyi ekonomichna efektyvnist' [Digitalization of agricultural enterprises and its economic efficiency]. Cherkasy: Chabanenko Yu. A. [In Ukrainian]. 
10. Pronyknennya Internetu $\mathrm{v}$ Ukrayini [Internet penetration in Ukraine] (2019) Retrieved from: https://inau.ua/sites/default/files/file/1910/dani_ustanovchyh_doslidzhen_2019_roku.pdf [In Ukrainian].

11. Ofitsiynyy sayt Derzhavnoyi sluzhby statystyky Ukrayiny. Naselennya Ukrayiny [Official site of the State Statistics Service of Ukraine] (2021) Retrieved from: http://www.ukrstat.gov.ua [In Ukrainian].

12. U «Diyi» mozhna otrymaty ponad 50 posluh [In «Actions» you can get more than 50 services] (2021) Retrieved from: https://www.pravda.com.ua/news/2021/03/30/7288317 [In Ukrainian].

13. Pro zatverdzhennya planu zakhodiv z realizatsiyi Kontseptsiyi rozvytku sil's'kykh terytoriy: Zakon Ukrayiny vid 19.07.2017. № 489 [On approval of the action plan for the implementation of the Concept of rural development: Law of Ukraine of 19.07.2017 № 489] (2017) Retrieved from: https://zakon.rada.gov.ua/laws/show/489-2017-\%D1\%80 [In Ukrainian].

14. Pro skhvalennya Kontseptsiyi rozvytku elektronnoho uryaduvannya v Ukrayini: Rozporyadzhennya Kabinetu Ministriv Ukrayiny vid 20.09.2017. № 649 [On approval of the Concept of e-government development in Ukraine: Order of the Cabinet of Ministers of Ukraine dated 20.09.2017 № 649] (2017) Retrieved from: https://www.kmu.gov.ua/npas/250287124 [In Ukrainian].

15. Pro skhvalennya Kontseptsiyi rozvytku elektronnoyi demokratiyi v Ukrayini ta planu zakhodiv shchodo yiyi realizatsiyi: Rozporyadzhennya Kabinetu Ministriv Ukrayiny vid 08.11.2017. № 797 [On approval of the Concept for the development of e-democracy in Ukraine and the action plan for its implementation: Order of the Cabinet of Ministers of Ukraine dated 08.11.2017 № 797] (2017) Retrieved from: https://zakon.rada.gov.ua/laws/show/797-2017-\%D1\%80 [In Ukrainian].

16. Pro vnesennya zmin do deyakykh postanov Kabinetu Ministriv Ukrayiny shchodo funktsionuvannya ofitsiynykh veb-saytiv orhaniv vykonavchoyi vlady. Postanova Kabinetu Ministriv Ukrayiny vid 19.06.2019. № 493 [On amendments to some resolutions of the Cabinet of Ministers of Ukraine on the functioning of official websites of executive bodies. Resolution of the Cabinet of Ministers of Ukraine of June 19, 2019 № 493] (2019) Retrieved from: https://zakon.rada.gov.ua/laws/show/493-2019-\%D0\%BF [In Ukrainian]. 